\title{
Intraosseous Schwannoma of the Radius
}

\section{Radius Yerleşimli İntraosseöz Schwannoma}

\author{
Pelin BAĞCI' , Sergülen DERVişoĞLU' ${ }^{\text {, Murat } \mathrm{HIZ}^{2} \text {, Kaya KANBEROĞLU }}$
}

Department of ${ }^{1}$ Pathology, ${ }^{2}$ Orthopedics and Traumatology and ${ }^{3}$ Radiology, ístanbul University, Faculty of Cerrahpaşa Medicine, ISTANBUL, TURKEY

\section{ABSTRACT}

Intraosseous schwannoma is a rare benign neoplasm arising from Schwann cells of the nerve sheath and involving the substance of bone. Intraosseous schwannomas account for less than $0.2 \%$ of primary bone tumors. The most common site of occurrence is the mandible, a characteristic traditionally attributed to the long intraosseous path of the inferior alveolar nerve.

Here we report a case of intraosseous schwannoma in the radius of a 19 year-old female which was misdiagnosed as a sarcoma.

Even it is a very rare lesion of bone one should be aware of the fact that when a small biopsy is taken, it can be misdiagnosed as sarcoma or fibrous dysplasia.

Key Words: Schwannoma, Intraosseous, Radius
ÖZ

İntraosseöz schwannoma sinir kılıfındaki Schwann hücrelerinden köken alan, nadir görülen, iyi huylu bir tümördür. Primer kemik tümörlerinin \% 0.2’sinden azını oluşturur. En sık görüldüğü kemik mandibuladır. Karakteristik olarak mandibulanın içinde, inferior alveoler sinirin yerleşik olduğu oluk boyunca görülür.

Bu makalede 19 yaşındaki bir bayan hastanın radiusunda yerleşen ve radyolojik olarak sarkom tanısı alan intraosseöz schwannoma olgusu sunulmuştur.

Çok nadir görülen bir lezyon olsa da, küçük biyopsilerde sarkom ya da fibröz displazi ile karışabileceği unutulmamalıdır.

Anahtar Sözcükler: Schwannoma, İntraosseöz, Radius

\section{INTRODUCTION}

Intraosseous schwannoma (neurilemmoma) is a rare benign neoplasm arising from Schwann cells of the nerve sheath and involving the substance of bone. Intraosseous schwannomas account for less than $0.2 \%$ of primary bone tumors (1). In the Mayo Clinic series of 11,087 primary bone tumors, 14 cases of intraosseous schwannoma were identified, accounting for fewer than $1 \%$ of these benign primary bone tumors (2). The most common site of occurrence is the mandible, a characteristic traditionally attributed to the long intraosseous path of the inferior alveolar nerve $(3,4)$. Other sites reported include the sacrum, vertebra, skull, maxilla, clavicle, scapula, sternum, ribs, humerus, radius, ulna, ilium, pubic bone, femur, patella, fibula, tibia, and bones of the hands and feet (5-10).

In this article, we report a case of intraosseous schwannoma of the radius.

\section{CASE REPORT}

A 19-year-old girl who had a traumatic fracture, was referred to our Department of Orthopedic Surgery with a 6-month

Received : 28.09.2009

Accepted : 11.12.2009 history of pain and swelling around the proximal region of the right radius and a pathologic fracture at the same region. On physical examination, there was minimal pain with pressure and no pain during the movements of elbow and wrist. The routine biochemical results were normal. Roentgenograms showed an expansile, lytic lesion, without cortical destruction involving the proximal portion of the radius (Figure 1). There was increased activity at the same part in the Tc-99m scintigraphy. Magnetic resonance (MR) imaging studies showed a $10 \mathrm{~cm}$ mass in medullary region that had soft tissue component without homogeneous pattern. Although the differential radiologic diagnosis from another center included firstly Ewing sarcoma and osteosarcoma; the lesion was defined by our Radiology Department as an intramedullary mass which seemed to be benign with a soft tissue heterogeneity. They offered fibrous dysplasia as a differential diagnosis (Figure 2).

Myofibroblastic and osteoblastic activity with focal spindle cell proliferation were seen at the tru-cut biopsy and the pathologic diagnosis was interpreted as 'healing pathologic fracture and the clinicians were informed that the focal

Correspondence: Pelin BAĞCI

Department of Pathology, İstanbul University,

Faculty of Cerrahpaşa Medicine, İSTANBUL, TURKEY

E-mail: apelinbagci@gmail.com Phone: +90 4642130492 


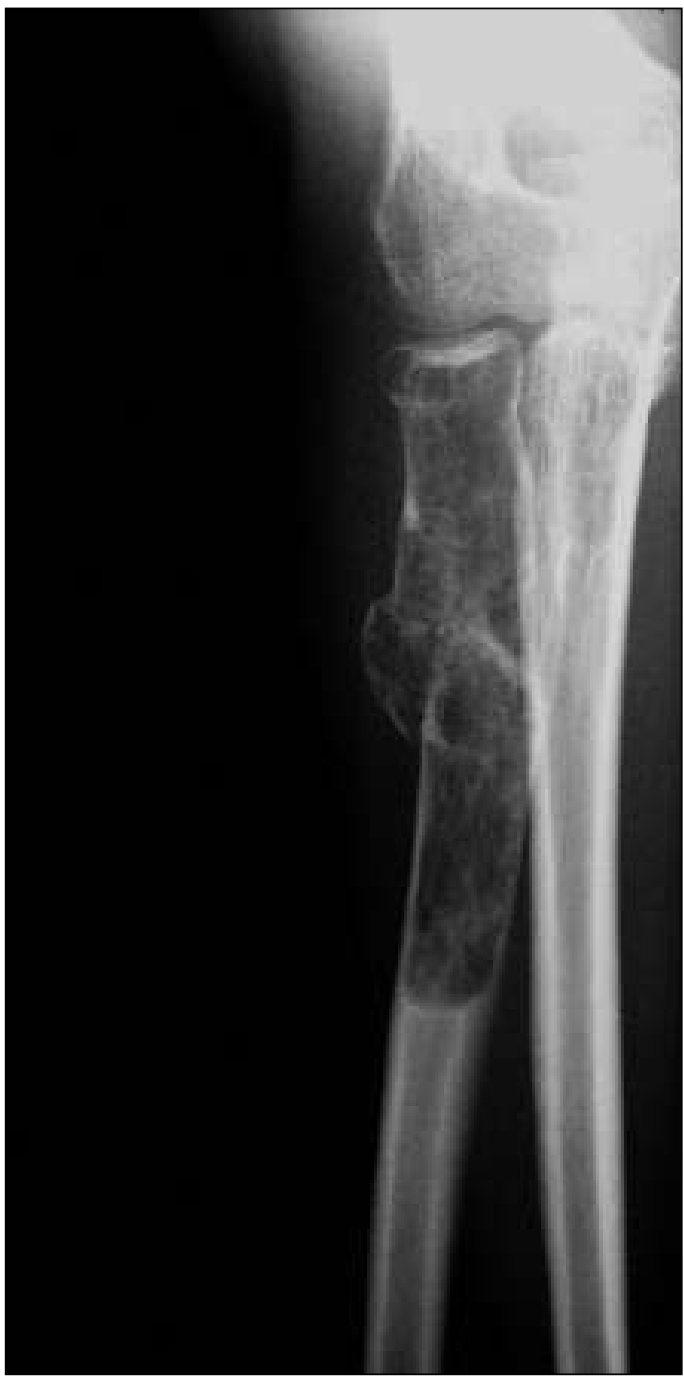

Figure 1: Pathological fracture caused by intramedullary located mass, X-ray.

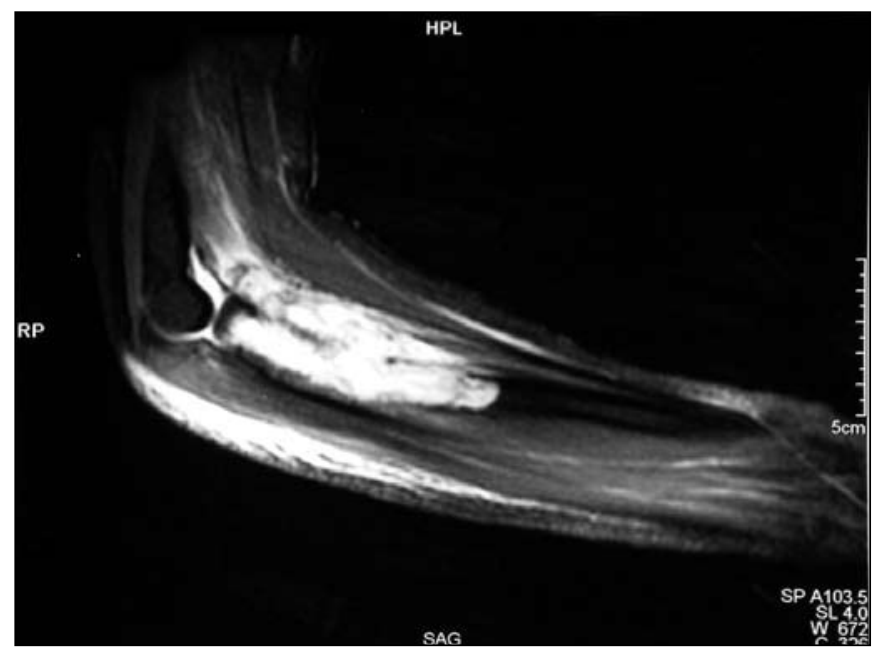

Figure 2: Intramedullary located mass of soft tissue density without cortical destruction in Magnetic Resonance Imaging. spindle cell proliferation was not enough to diagnose a fibrous dysplasia and resection was planned. After 3 months, at the peroperative examination the cortex was intact and the fracture was seen totally healed and curettage was done instead of resection by the accompaniment of frozen-section. The material was $2 \mathrm{cc}$ haemorragic elastic tissue with small bone particles in it. The final diagnosis was left to the paraffin sections at the time, and the operation was ended after cortical and medullar material was taken from the lesion site.

Microscopic examination of the hematoxylene-eosinstained sections of the curettage specimen revealed foci of Antoni type-A areas including spindle cells arranged with palisading, ovoid, basophilic nuclei and acidophilic cytoplasm, and Antoni type-B areas. Acellular, eosinophilic areas described as Verocay bodies were also noted. As it was a curettage material, the borders and the capsule of the lesion could not be examined (Figure 3 and 4). Immunohistochemical examination revealed positive results for S100 and PGP 9.5 protein (Figure 5 and 6). The histological diagnosis was primary intraosseous schwannoma of the radius. No recurrence was observed in the follow-up study at 45 months.

\section{DISCUSSION}

Intraosseous schwannoma is a rare bone tumor and represents less than $1 \%$ of all primary bone tumors. Fewer than 200 examples of this entity have been described in the literature and this is the first case from our department. The mandible and sacrum are the most common sites and it can also be seen in skull, rib, scapula, long bones, metacarpals, spine, phalanges and patella (11). Radius localization has been aforementioned in the reviews, but there is only one

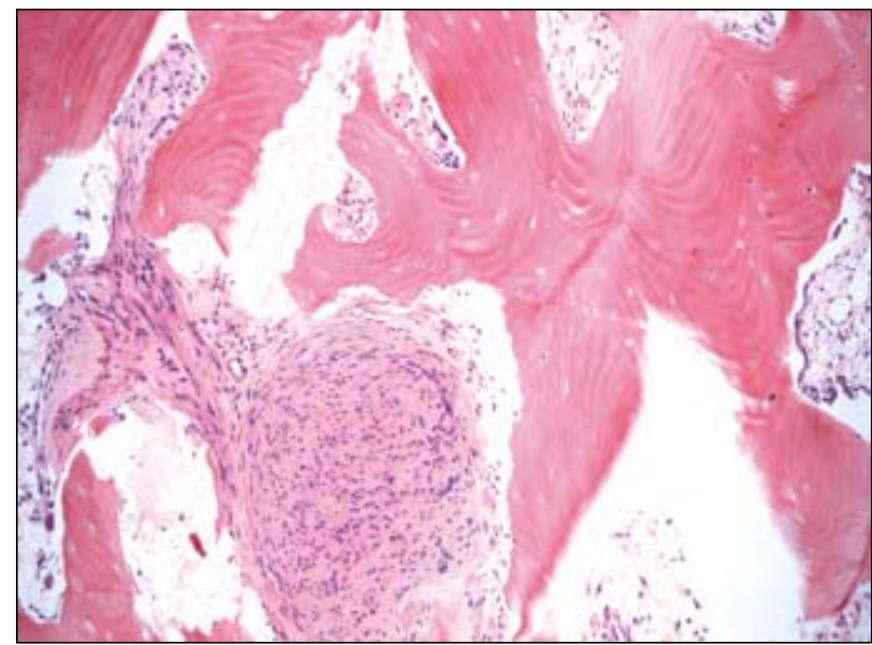

Figure 3: Intramedullary tumor (H\&E, x100). 


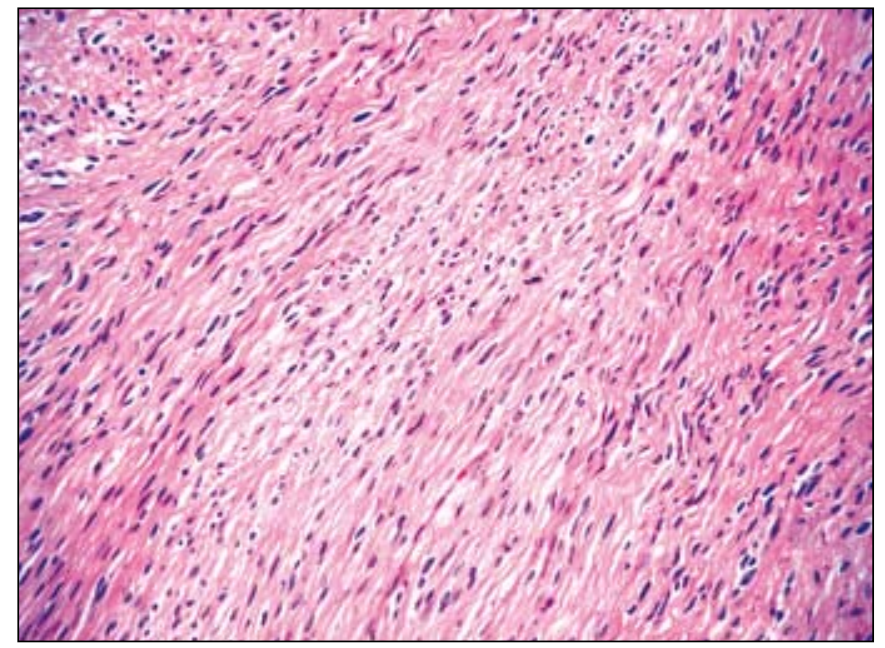

Figure 4: Histopathological appearence of a typical schwannoma, Antoni-A areas (H\&E, x200).

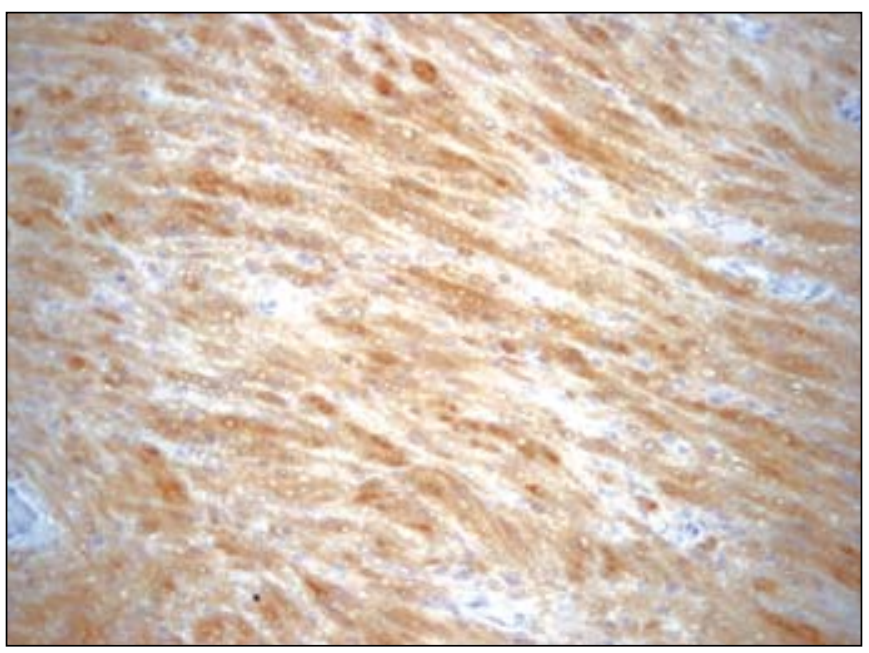

Figure 5: Immunohistochemical technique, PGP 9,5 primary antibody (DAB, x400).

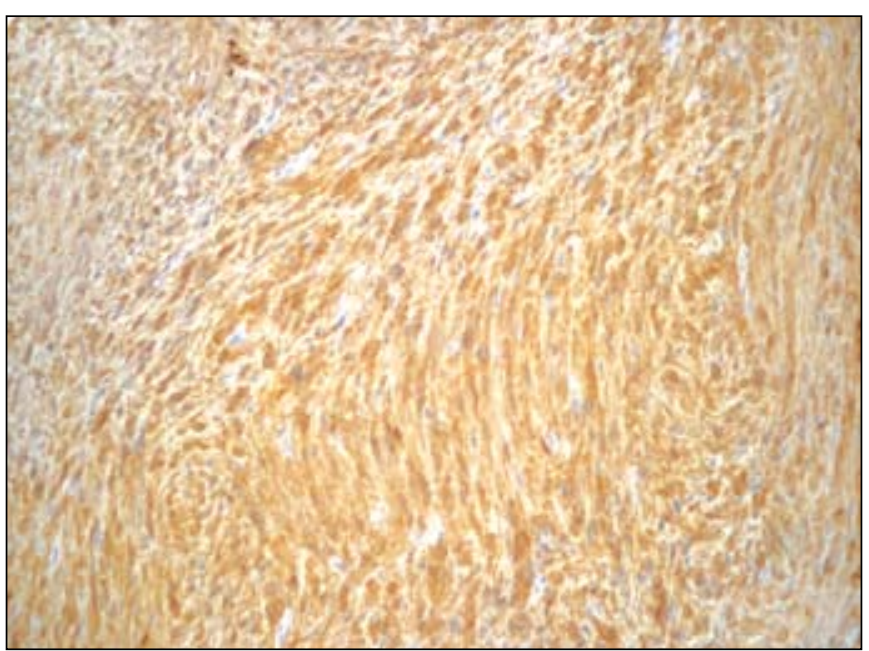

Figure 6: Immunohistochemical technique, S100 primary antibody (DAB, x400). case located in the radius in the English literature, according to our knowledge (12). Although there is no specific distribution for age and sex when a review of the literature revealed that male: female ratio was 3:4, and the patients were mostly in their second and third decade of life.

Schwannoma can involve bone by three mechanisms: 1) secondary erosion by an extraosseous tumor, 2) tumor arising from a nerve coursing through a canal in a bone and causing erosion of the bone, creating a dumbbell-shaped configuration or 3) tumor arising centrally (intramedullary) in a bone. The first two mechanisms occur most frequently (13). As there was no extraosseous mass, we thought the 2nd or the 3rd mechanism was the possible reason in our case. But no clue was found about the adjacent nerve bundles in the curettage specimen. We can assume that the 3rd mechanism is the the most probable mechanism way in our case, as there is no recurrence since the operation.

The radiological appearance is a well-circumscribed, occasionally multilocular osteolysis with inconstant peripheral osteosclerosis, thinning without rupture of the cortex and no soft-tissue invasion, no periosteal reaction, and no intratumoral calcification (14). But, as happened in our case, if there is a healing pathologic fracture, the radiological images could be misdiagnosed as bone sarcoma.

Macroscopically it is a soft, tan-gray lesion with frequent yellowish patchy areas. Haemorrhage, myxoid, and cystic changes are frequently present. When the lesion is present in a neural canal or foramina, a capsule may be discernible. There is no invasion of surrounding medullary bone $(2,13)$.

Microscopic features are similar to those of their more common counterparts. The tumors have two basic patterns: hypercellular (Antoni A) and hypocellular (Antoni B) areas. In Antoni $\mathrm{A}$ areas of schwannoma cells that are compactly arranged form focally palisading structures (Verocay bodies). In Antoni B areas, schwannoma cells are widely separated by a loose intervening collagenous matrix. Vessels with thick hyalinized walls are present focally. Variable numbers of histiocytes, macrophages, lymphocytes, and mast cells may be present. Some variants are hypercellular and may have less distinguishible Antoni A and $\mathrm{B}$ areas. These lesions may exhibit some nuclear atypia, and occasional mitoses may be present. These tumors are compatible with so-called cellular schwannomas and should be carefully differentiated from malignant neoplasms. There is no evidence of malignant potential for this tumor in the English literature. Ultrastructural features of intraosseous schwannomas are the same as those described for soft tissue 
schwannomas. Immunohistochemically, the tumor cells are positive for vimentin and S-100 protein (13).

It is easy to make the differential diagnosis from a sarcoma, if the biopsy is taken only from the tumor. Although degenerative atypia which is a common feature of neural tumors and may cause problems in differentiating these tumors from spindle cell sarcomas, it is important to remember that atypical mitoses are never seen in benign Schwannoma while it is a common feature of sarcomas (13). Differential diagnosis of schwannoma in small biopsy taken from the pathologic fracture zone is a complicated situation as we experienced in our case. The biopsy sample complicated with fracture healing process may produce a diagnostic dilemma. Especially if the sample is containing the nonrepresentative area of a heterogeneous lesion, misinterpretation of the biopsy is inevitable. Likewise fibroblastic and myofibroblastic activity without bone of a healing or healed pathologic fracture zone can be misdiagnosed as any spindle cell tumor including schwannoma. On the other hand since intraosseous schwannomas are rare tumors and because of lytic rarefactions and sometimes bubbly appearance with irregular borders, they may be misinterpreted as fibrous dysplasias radiologically (2). When the small biopsy specimen is examined as in our case with this radiologic prediagnosis, fusiform-shaped cells of schwannoma may cause diagnostic overlapping with fibrous component of fibrous dysplasia, especially when the material is lacking typical wowen bone of fibrooseeous lesion. Although they are rare in occurrence when a spindle cell lesion is evaluated from a tru-cut biopsy material intraosseous schwannomas must be kept in mind in the differential diagnosis along with other spindle cell lesions such as desmoplastic fibroma, nonossifying fibroma and fibrous dyplasia (13). Cytological examination helps to reveal the Schwannian (wavy), fibroblastic (spindle) or myofibroblastic (plumpy) features of the nucleus. In addition to cytological features immunohistochemistry panel containing SMA, S-100 protein and Ki-67 can be used as an ancillary diagnostic tool. Clinicopathological multidisciplinary approach and evaluation of complicated cases along with radiological findings may also help in solving the diagnostic problems in rare bone tumor cases such as intraosseous schwannoma.

\section{REFERENCES}

1. Fawcett KJ, Dahlin DC: Neurilemmoma of bone. Am J Clin Pathol 1967, 47:759-766

2. Unni KK: Dahlin's bone tumors. General aspects and data on 11,087 cases, 5th edn, Philadelphia, Lippincott-Raven, 1996, 343347

3. Meyer A, Sailhan F, Coulomb A, Thevenin-Lemoine C, Mary P, Ducou-Lepointe H, Damsin JP: Proximal tibial epiphyseal intraosseous schwannoma, a rare entity. J Pediatr Orthop 2008, 28:786-790

4. Nakasato T, Katoh K, Ehara S, Tamakawa Y, Hoshino M, Izumizawa M, Sakamaki K, Fukuta Y, Kudoh K: Intraosseous neurilemmoma of the mandible. AJNR Am J Neuroradiol 2000, 21:1945-1947

5. Chi AC, Carey J, Muller S: Intraosseous schwannoma of the mandible: A case report and review of the literature. Oral Surg Oral Med Pathol Oral Radiol Endod, 2003, 96:54-65

6. Chevalier X, Montazel JL, Voisin MC, Hernigio P: Intraosseous neurilemmoma of the lower third of the fibula. AJR 1995, Letters: $165,1555-1556$

7. Erşahin Y, Mutluer S, Demirtaş E: Intraosseous neurinoma of the parietal bone. Child's Nerv Sys, 2000, 16:181-183

8. Goyal R, Saikia UN, Vashishta RK, Gulati G, Sharma RK: Intraosseous schwannoma of the frontal bone. Orthopedics, 2008, 31:281

9. Mutema GK, Sorger J: Intraosseous schwannoma of the humerus. Skeletal Radiol, 2002, 31:419-421

10. Nannapaneni R, Sinar EJ: Intraosseous schwannoma of the cervical spine. Br J Neurosurg 2005, 19:244-247

11. Turk PS, Peters N, Libbey PN, Wanebo HJ: Diagnosis and management of giant intrasacral schwannoma. Cancer 1992, 70: 2650-2657

12. Giné J, Calmet J, Sirvent JJ, Domènech S: Intraosseous neurilemmoma of the radius: a case report. J Hand Surg Am 2000, 25:365-369

13. Dorfman HD, Czerniak B: Bone tumors, St. Louis, Mosby, 1998, 825-831

14. Agha FP, Lilienfeld RM: Roentgen features of osseous neurilemmoma. Radiology 1972, 102:325-326 